International Research Journal of Management, IT \& Social Sciences
Available online at https://sloap.org/journals/index.php/irjmis/
Vol. 9 No. 1, January 2022, pages: 203-220
ISSN: 2395-7492
https://doi.org/10.21744/irjmis.v9n1.2010

\title{
The Role of Celebrity Endorsements in Breaking Advertising Clutter and reducing Advertising Avoidance on Social Media Networks
}

Article history:

Submitted: 27 November 2021

Revised: 09 December 2021

Accepted: 18 January 2022

\section{Keywords:}

advertising avoidance; advertising clutter; attractiveness; celebrity endorsement; expertise; trustworthiness;

\begin{abstract}
In the light of the business environment dominated by marketing noise and advertisements that surround us from every angle, relying on the popularity of social networks has become insufficient to pass advertising messages into the minds of the customers. We live today amid a sea of advertising clutter that undermined the efforts of marketers in conveying their voices to target customers. Besides, technology has given customers greater opportunities to choose the appropriate way to deal with advertising messages, whether by ignoring or blocking them. Therefore, the study sought to reveal the extent of the existence of advertising clutter on social media networks and its relationship to advertising avoidance, and then determine the role that celebrity endorsement can contribute to breaking this clutter and reducing advertising avoidance. The study adopted the quantitative approach in measuring its variables by surveying a large sample of Iraqi social network users, which numbered (837) respondents. The study concluded that advertising clutter on social networks has reached unjustified and unwelcome levels. Moreover, the results confirmed that the celebrity endorsement strategy has a prominent role in penetrating clutter and reducing advertising avoidance.
\end{abstract}

International research journal of management, IT and social sciences (C) 2022. This is an open access article under the CC BY-NC-ND license (https://creativecommons.org/licenses/by-nc-nd/4.0/).

\section{Corresponding author:}

Raafat Awad Mosa,

University of Basrah, College of Admin \& Economics.

Department of Business Admin, Iraq.

Email address: raafat.musa@uobasrah.edu.iq

${ }^{\mathrm{a}}$ University of Basrah, Iraq 


\section{Introduction}

In a world where the marketing hype and advertising clutter prevail (Li, 2018), Attracting customers' attention has become a difficult goal for most marketers (Nilsson, 2006; Rafique \& Zafar, 2012). Today, the advertising landscape appears to be more rapid in growth, with advertisements flooding our daily lives and extending to fill the remaining "empty spaces" in our societies. The competition as a prominent feature of the current business environment has led marketers to believe that penetrating advertising clutter is linked to the expression "Shout out so that others can hear you". The reality reveals that the orientations of many marketers in their promotional thinking and practices revolve around adopting a lottery-like mechanism in wasting money to gain customer interest by sending a huge number of advertising messages and repeating the number of appearances in various communication media (Anderson \& Palma, 2013; Rogala, 2015). However, the promotional attempts of marketers often collide with the trends of similar competitors, and these efforts are ultimately lost among the sea of advertising messages that constantly hit customers (Muda et al, 2012; Subramanian, 2015). More precisely, marketers are currently facing the obstacle of clutter that has squandered the advertising efforts to get their voices across to their target market (Martin \& Smith, 2008). In return for this, the interests of many of these marketers focused on bombarding customers with more advertisements. So, most customers suffer from the constant invasion of advertisements and they are devoid of emotion towards many of them (Malik \& Qureshi, 2016).

Historically, marketers have long aspired to employ media that enables them to address target customers, starting with the use of traditional media such as flyers, posters, radio, billboards, and television to what is known as digital networks recently (Adelabu, 2015). The emergence of digital networks has brought about noticeable changes in the prospects of marketing after social media networks have replaced the traditional media of communication with customers (Truong \& Simmons, 2010; Ordenes et al, 2018). In particular, after the Corona epidemic, platforms such as Facebook, Instagram, YouTube, and Twitter have become that virtual world that attracts billions of customers, and they spend long hours browsing it (Khan, 2017; Chen, 2021). Furthermore, social media networks have changed the way customers consume and interact with information (Vukasovic, 2013; de Luca et al., 2019). These networks emerged as virtual communities that allow the exchange of opinions and sharing of information between humans as well entertainment, but they quickly turned into the largest commercial platforms (Belanche et al. 2017). In recent years, the domain of marketers' use of social media platforms in their advertising practice has expanded, with advertising spending on those networks reaching billions of dollars (Neti, 2011; Mattke et al., 2018). Consequently, estimates indicate that customers are exposed to a wide number of ads on social media networks, which reach thousands of messages per day, this will inevitably reflect in their sense of clutter and generate the opposite behavior in advertising avoidance (Goh, 2018; Chinchanachokchai \& de Gregorio, 2020).

Despite the increasing pace of advertising spending on social media networks, there appears to be a lack of strategic thinking about the ability of ads on such networks to gain customer attention (Truong \& Simmons, 2010). Mostly, the chaotic marketing environment provides an unsuitable ground for achieving advertising spread, and this applies to traditional media as well as social media networks such as Facebook (Nelson-Field et al., 2013). Specifically, an environment such as the Internet had a clear role in enabling customers to easily avoid advertising content on social media networks (Kelly et al., 2010; Jagani \& Goldsmith, 2018). Besides, the effectiveness of advertising amid the current advertising clutter can collide with the ability of the human mind to process a huge amount of information and remember the advertising messages (Lee \& Cho, 2010). Hence, flooding customers with advertisements through the online environment poses an obstacle to marketers' ability to design an effective advertising message and exacerbates clutter (Rotfeld, 2006; Falcao \& Isaias, 2020), this is what prompted marketers to search for ways in which they can penetrate the advertising clutter (Das, 2018). For most marketers, their compass has turned toward the common way to break the advertising clutter using celebrity endorsements (Magnini et al., 2008; Dzisah \& Ocloo, 2013), Which has been described by many studies as the strategy that can gain the attention of the customer in a business environment that suffers from severe advertising clutter (Dzisah \& Ocloo, 2013; Hung, 2014; Erdoğmuş \& Ergun, 2016).

\section{Problem and objectives of the study}

At a time when marketers seem to focus clearly on choosing social media networks as channels that transmit their voices to a wide audience of customers, it is noted that there is little interest in questions and research discussions about the effectiveness of advertising on these networks in gaining customer interest amid clutter (Truong \& Simmons, 2010). Frankly, the phenomenon of advertising clutter and its associated negative outcomes have not received sufficient research interest in a digital networking environment that has expanded customers' ability to control what they receive 
from advertising (Ouyang, 2015), It can be said that the practices of marketers in sending more advertising messages on social media networks are no longer sufficient to penetrate the clutter and reach the customer's mind (Jagani \& Goldsmith, 2018). Instead, these messages backfired, exacerbating customer reactions to advertising avoidance (Mendez et al., 2009; Kelly et al., 2010). Thus, marketers need to develop strategies that enable them to Design advertising messages that capture the attention of customers (Koshksaray et al., 2015). Therefore, the study sought to measure the level of perceived advertising clutter among Iraqi social media networks users and its impact on their behavior in advertising avoidance, and then shed light on the role that celebrity endorsement can play in Breaking advertising clutter and reducing advertising avoidance on those networks.

\section{Study questions}

The study attempts to answer the following questions:

Q1. What is the extent of the existence of advertising clutter on social media networks from the point of view of Iraqi users?

Q2. To what extent does advertising clutter affect advertising avoidance among Iraqi social media networks users?

Q3. How does celebrity endorsement affect advertising clutter and advertising avoidance among Iraqi social media networks users?

\section{Literature review}

Celebrity endorsement

The concept of celebrity endorsement and its importance

Celebrity endorsement is among the promotional strategies that have been at the topped of the advertising landscape for a long period, and it is still receiving wide interest from researchers and marketing practitioners (Ndlela \& Chuchu, 2016). With the increasing popularity of film and television stars between the 1920s and 1930s, audiences began to glorify, follow, and imitate stars in areas including clothing, haircuts, make-up, and even speech and behavior (Kowalewska, 2018). The term celebrity in its simplest form describes a person who is known to the people and the media, as he/she is considered a role model for others (Freire et al., 2018). Schlecht (2003), Celebrities are defined as "persons who command the outstanding attention of a broad spectrum of the public". Personalities such as artists, athletes, musicians, and singers have become models that appeal to a large number of audiences (Schouten et al., 2020), those personalities gain their fame from the charismatic and likable traits they possess that are seen by others as the personal dimensions that distinguish the celebrity from the general public (Hussain \& Khan, 2017). Endorsements refer to the way a celebrity offers or speaks about a product on behalf of a company (Dhotre \& Bhola, 2010).

Regardless of their educational and social roles, celebrity endorsement is a tactic widely employed by marketers in promoting a wide variety of products (Awasthi \& Choraraia, 2015), Such people have strong magic in different areas of life, which marketers use to influence the public and persuade them to buy (Cuomo et al., 2019). Celebrity endorsement is also one of the clear trends in advertising practices through which marketers seek to differentiate their products and services from their competitors (Jolly \& Mynavathi, 2013; Hani et al., 2018). The reality shows that celebrities in the field of marketing are receiving wide attention from the public due to their having the ability or resources that have a prominent role in influencing the course of marketing events (Gupta, 2009; Olmedo et al., 2020). For this reason, many marketers are increasingly investing the celebrity endorsement strategy in their advertising campaigns to create product awareness and motivate customers to buy (Freire et al., 2018; Ifeanyichukwu, 2016). Previous research has confirmed that celebrity endorsement is a powerful strategy in conveying advertising messages about a particular brand to the target market, it gives an additional advantage to the product in the eyes of customers through the words and admiration of celebrities for that product (Nelson \& Deborah, 2017). Moreover, celebrity endorsements help to better store and retrieve information about advertised products in the minds of customers (Sharma \& Kumar, 2013). Thus, higher ratings for a product or a brand endorsed by celebrities will increase sales and profits (Magnini et al., 2008).

\section{Dimensions of celebrity endorsement}

Celebrities within the scope of marketing can do wonders for a product as well as harm it (ForgDog, 2013). on this point, Sharma \& Kumar (2013), emphasized that the need to pay attention to the fact that celebrity endorsement cannot be seen as a solution or panacea to overcome the difficulties that stand in the way of advertising effectiveness without

Mosa, R. A. (2022). The Role of Celebrity Endorsements in Breaking Advertising Clutter and reducing Advertising Avoidance on Social Media Networks. International Research Journal of Management, IT and Social Sciences, 9(1), 203-220. https://doi.org/10.21744/irjmis.v9n1.2010 
taking into account the correct employment of those Persons. Hence, the development of an advertising strategy employing celebrity endorsement to effectively affect the target audience should be based on the endorser's possession of three qualities or dimensions (attractiveness, trustworthiness, and expertise), which are briefly explained below:

\section{- Attractiveness}

Attractiveness is the most important dimension in the success of advertising (Mailk \& Sudhakar, 2014), it is an expression of the stereotype of the positive relationship between the audience and the celebrity based on the attractiveness of the body and face (Mishra, 2015). Advertising techniques focus on the idea that beauty is a powerful motivator in attracting and convincing customers. Physical attractiveness is the primary measure through which we launch our judgments on others. Undoubtedly, the appearance of a celebrity is more important than the strength of his arguments and how he supports those arguments, for example when advertising beauty products, the beauty of a celebrity is more convincing than the image of the product itself (Raluca, 2012). Thus, it is more likely that a celebrity with a charming appearance will receive approval and rating that will resonate better and faster with the audience compared to a character whose attractiveness is weak in advertising (Nguyen, 2021). Certainly, the celebrity with physical attractiveness exerts a stronger influence on the perceptions, attitudes, and purchasing intentions of customers.

\section{- Trustworthiness}

Trustworthiness refers to the degree of objectivity and credibility with which the public perceives information provided by a celebrity (Manran, 2019). Trust stems from the integrity, reliability, and acceptability of the celebrity person and what he/she claims about the product in terms of features and benefits (Raluca, 2012; Subbiah \& Sathish, 2020). When a celebrity is untrustworthy, attractiveness will not affect the target market. On the other hand, the customer will not scrutinize the same ad that has received a trustworthy celebrity endorsement, and that customer may release his positive judgments directly without thinking (Freeman \& Chen, 2015). In this direction, the results of previous research indicate that trustworthy celebrities have stronger persuasive power in the target audience compared to celebrities who are untrustworthy, as customers are affected at an easier and faster level by the celebrity person who gets their trust (Wang \& Scheinbaum, 2017; Schouten et al., 2020; CalvoPorral et al., 2021).

\section{- Expertise}

The third component in crafting an influential celebrity endorsement strategy is expertise, it refers to "the image in which the customer perceives the celebrity person as a source of valid claims and assertions" (Hocevar et al., 2017). In other words, expertise reflects the knowledge and skill that the celebrity possesses about the advertised product or brand (Schouten et al., 2020). Frankly, expertise is a vital factor in influencing the customer's perception of the validity of the claims made by the celebrity in the advertisement, specifically when the product has technical specifications that require expertise more than attractiveness (Manran, 2019; Christian, 2020). Thus, celebrities with extensive expertise can gain positive recognition from customers and motivate them to buy more aggressively (Nguyen, 2021).

\section{Advertising clutter \\ Definition of advertising clutter and its results}

In a simple concept, clutter refers to a state of confusion and noise that may encounter an individual in his life as a result of the many elements and things that surround him (Rosenholtz et al., 2005). The term advertising clutter has been used in the marketing literature interchangeably with other names such as marketing clutter (Subramanian, 2015), cluttered market (Magnini et al., 2008; Jain, 2012), But the term Advertising Clutter is the most commonly used compared to other terms (Rotfeld \& Stafford, 2006; Teixeira \& Stipp, 2013; Negm \& Tantawi, 2015). Matter of fact, most of the researchers' views tended towards defining advertising clutter as a wide number of advertisements that confront the customer in the means of communication and technology used in daily life, which undesirably exceeds the acceptability (Damour, 2019; Brown \& Point, 2011). Most of the marketing research has agreed that advertising clutter is only a natural result produced by the communications environment, which is characterized by high noise and hype (Hammer et al, 2009).

Regardless of the levels of advertising clutter, it constitutes a stumbling block for marketers in achieving their goals, because it is difficult in the midst of a chaotic business environment for their voices to reach the target customers ( $\mathrm{Al}$ 
Shuaili, 2016). In general, advertising clutter will negatively affect the level of advertising effectiveness in achieving the desired effects on customers (Tanjung \& Hudrasyah, 2019). The negative effects that will be generated by the marketing environment characterized by advertising clutter can be summarized in the following points:

- Advertising clutter reduces the customer's desire to see the advertisement (Hammer et al., 2009), and in a broader meaning that customers will pay little attention and perhaps be indifferent to the many advertisements they receive (Damour, 2019).

- The Customers will simply deal with the advertisements by avoiding or ignoring them (Keller, 2009). The Internet and its associated communication technologies have enabled customers to more easily control what they want to watch and what they want to interact with, for example using ad-blocking programs (Guardia \& Lopez, 2014).

- Advertising clutter is negatively reflected in the customer's ability to remember the product or brand contained in the advertising messages (Ha \& McCann, 2008).

- The clutter creates an unfavorable emotional response from the customer towards the advertisement or questioning its content, this generally affects the decrease in the desire or intent to buy.

\section{Dimensions of advertising clutter}

Advertising clutter in social media networks is often attributed to two main dimensions (Advertisements Quantity, competitive interference), and these dimensions are summarized as follows:

\section{- Advertisements quantity}

The first dimension in advertising clutter is related to the number or percentage occupied by ads in digital media (Goh, 2018), which means an unjustified or desirable increase in the quantity or amount of advertising (Rosengren \& Dahlén, 2006). Many marketers believe that the inability of advertising to attract the attention of the customer means that the opportunity to communicate with him is lost. Thus, it is supposed to intensify the advertising efforts to create awareness and consolidate the content of the advertisement in the mind of the customer (Nilsson, 2006). In light of the increasing use of digital networks in advertising and promotion by marketers, advertising clutter on social media networks has begun to appear similar to traditional media such as television. Although the year 2020 has recorded an increase in the number of users of social networks due to the Corona epidemic, the same statistics remind that the customer's behavior has changed towards not following many brands, and among the main reasons behind this is the presence of the huge number of ads on those networks (Chen, 2021).

- Competitive interference

The term competitive interference means the degree or level of similarity and closeness between the advertised products among the brands that appear within the product category in a particular advertising channel or medium, where the level of customer confusion increases and brands are difficult to remember when the products advertised are very similar (Rosengren, 2008). In this context, it is indicated that competitive clutter has a greater impact than quantity clutter on advertising effectiveness and brand recall in customer memory (Nan \& Faber 2004). For this reason, there is a wide focus of academics and marketers on finding solutions to the problem of interference to enhance the effectiveness of advertising (Al Shuaili, 2016). Nowadays, Competitive interference is among the strong challenges facing marketers in their quest to reach the customer's attention. Therefore, many of those marketers and advertising agencies have turned to the adoption of entertainment as a supportive aspect to attract a wide advertising view (Teixeira \& Stipp, 2013). generally, a well-known and familiar brand is less sensitive to clutter or competitive interference than a new and unfamiliar brand (Rosengren \& Dahlen, 2006).

\section{Advertising avoidance (definition and level)}

The concept of advertising avoidance expresses actions taken by digital media users related to reducing exposure to advertisements during their search and entertainment journey on its various platform (Speck \& Elliot, 1997), Simply, advertising avoidance describes a situation in which customers consciously and deliberately tend to avoid the stimulus of advertising they see in social media Networks (Koshksaray et al., 2015), it is known that many customers are bothered by advertisements and tend to avoid them in most cases (Niu et al., 2021). So, understanding customer

Mosa, R. A. (2022). The Role of Celebrity Endorsements in Breaking Advertising Clutter and reducing Advertising Avoidance on Social Media Networks. International Research Journal of Management, IT and Social Sciences, 9(1), 203-220. https://doi.org/10.21744/irjmis.v9n1.2010 
avoidance of advertisements has been of interest to researchers and marketing practitioners for a long time, and advertisement avoidance has been recognized as one of the difficult challenges facing marketers (Dong, 2019). In this point, a lot of research explored early avoidance of advertising on traditional media such as radio, Newspapers, television ...etc. and the results indicated that avoidance behaviors were divided between ignoring the advertisement, changing the TV channel (Mattke et al., 2018). In reality, advertising avoidance is a behavior closely related to the general attitude of the public towards advertising, which reflects a state of disinterest, aversion, and boycott of products or the brand (Ho, 2021).

Although the phenomenon of advertising avoidance is inherent in all communication media, whether traditional or non-traditional, it has taken a clear turn in the context of digital networks after Internet-related technologies have enabled customers to use many programs to block and avoid advertisements on social media networks (Seyedghorba et al., 2016; Onisor \& Ioniat, 2021). In this aspect, studies revealed that the avoidance of advertising on media related to the Internet was at a higher rate than the traditional means, given that the Internet embodies one of the applications of technology that gave customers a greater opportunity for advertisements avoidance (Richards, 2020; Niklas, 2021). Regardless of how advertising is ignored in digital networks, ads are often seen as disturbing or hindering the rate of connection of data required by users of those networks, so most behaviors dealing with marketing messages tend to be banned or ignored (Vratonjic et al., 2013). In general, the behavior of advertising avoidance moves in two paths or levels (Cognitive, Behavior) (Tran, 2017; Wijenayake \& Pathirana, 2019), which can be presented briefly as below:

- Cognitive: mental or cognitive avoidance of advertising refers to consumers' lack of interest in or ignoring advertisements (Kim, 2015; Lin et al, 2021).

- Behavior: Behavioral advertising avoidance describes actions that consumers take to avoid advertisements such as clicking a skip ad button (Li \& Huange, 2016).

\section{The link between the study variables and hypotheses development}

Despite the growing popularity of social media networks that have achieved more traffic than expected (Adelabu, 2015). However, these networks often suffer from "noise" and "clutter" about the ads launched on their platforms, this constitutes a major obstacle that reduces the effectiveness of those ads (Nelson-Field et al., 2013). According to Cowden (2014), the advertising clutter in social media networks has reduced the effectiveness of advertising messages so that ads on Facebook began to take a path similar to traditional means of communication. Likewise, Mattke et al. (2018), indicated that users of social networks face advertising clutter that hinders their search for information, and this clutter repeats the previous negative expertise of those users with traditional means of communication, and this is what prompts many of these to avoid advertising. Li et al. (2020), points out that many marketers choose social networking sites to spread their advertising messages to achieve widespread, but a large number of those messages are avoided. Gutierrez \& Otero (2020), revealed that the various advertising messages from videos and publications that appear while the user browses social networks may activate a state of perceived clutter, especially Facebook, generating the feeling that social networks do not are outside the framework of being commercial platforms. Niu et al. (2021), reported that the increasing popularity of social media networks has attracted the interest of many marketers to promote their products, and these marketers expect that their advertising messages will pass easily to the customer's mind, but the truth reveals the reactions of most customers that contradict the expectations Marketers by ignoring a lot of ads. Lin et al. (2021), stated that the YouTube platform considers ads while users are watching skippable videos, as an important financial return for both the site itself and the marketers who create advertising content, however, the ads generate annoyance among viewers, which many customers face by skipping or avoidance.

Certainly, technological developments have brought about digital transformations in the space of marketing, but the advertising clutter on digital networks and the resulting avoidance behaviors represent a blatant threat to the effectiveness of such advertisements, marketers currently need to distinguish their advertising messages between the hype of those platforms (Ouyang, 2015; Isosuo, 2016). Wherefore, marketers should draw a strategy that can overcome the clutter and generate the desired response from customers. on this subject, previous studies indicated that celebrity endorsement as a promotional tool has proven successful in penetrating the advertising clutter (Mude et al, 2012; Tanjung \& Hudrasyah, 2019; Hussain \& Khan, 2017), effective transmission of marketing messages ( Erdoğmuş \& Ergun, 2016; Saleem, 2017). Dhotre \& Bhola (2010), added that celebrity endorsements are an effective technique for communicating with the target audience and that they serve two important purposes: overcoming advertising clutter and creating interest in the advertising. Poturak \& Kadric (2013), described the advertising clutter that we face in our lives as reaching dangerous levels, the celebrity endorsement represents the effective tool to penetrate this clutter and 
achieve customer attention. Cuomo et al. (2019), indicated that celebrity endorsements constitute a marketing strategy capable of penetrating advertising clutter and generating interest in the product or brand. In light of the discussions and evidence presented by the studies above, the study proposes the following hypotheses:

H1: Advertising clutter has a significant impact on advertising avoidance among Iraqi users of social media networks

H1-A: ads quantity has a significant impact on advertising avoidance among Iraqi users of social media networks.

H1-B: Competitive interference has a significant impact on advertising avoidance among Iraqi users of social media networks.

H2: Celebrity endorsement has a significant impact on Breaking the Advertising clutter among Iraqi users of social media networks

H2-A: Celebrity attractiveness has a significant impact on Breaking the Advertising clutter among Iraqi users of social media networks.

H2-B: Celebrity trustworthiness has a significant impact on Breaking the Advertising clutter among Iraqi users of social media networks.

H2-C: Celebrity expertise has a significant impact on Breaking the Advertising clutter among Iraqi users of social media networks.

H3: Celebrity endorsement has a significant impact on reducing Advertising avoidance among Iraqi users of social media networks.

H3-A: Celebrity attractiveness has a significant impact on reducing Advertising avoidance among Iraqi users of social media networks.

H3-B: Celebrity trustworthiness has a significant impact on reducing Advertising avoidance among Iraqi users of social media networks.

H3-C: Celebrity expertise has a significant impact on reducing Advertising avoidance among Iraqi users of social media networks.

The proposed hypotheses of the relationship between the study variables can be illustrated in figure 1.

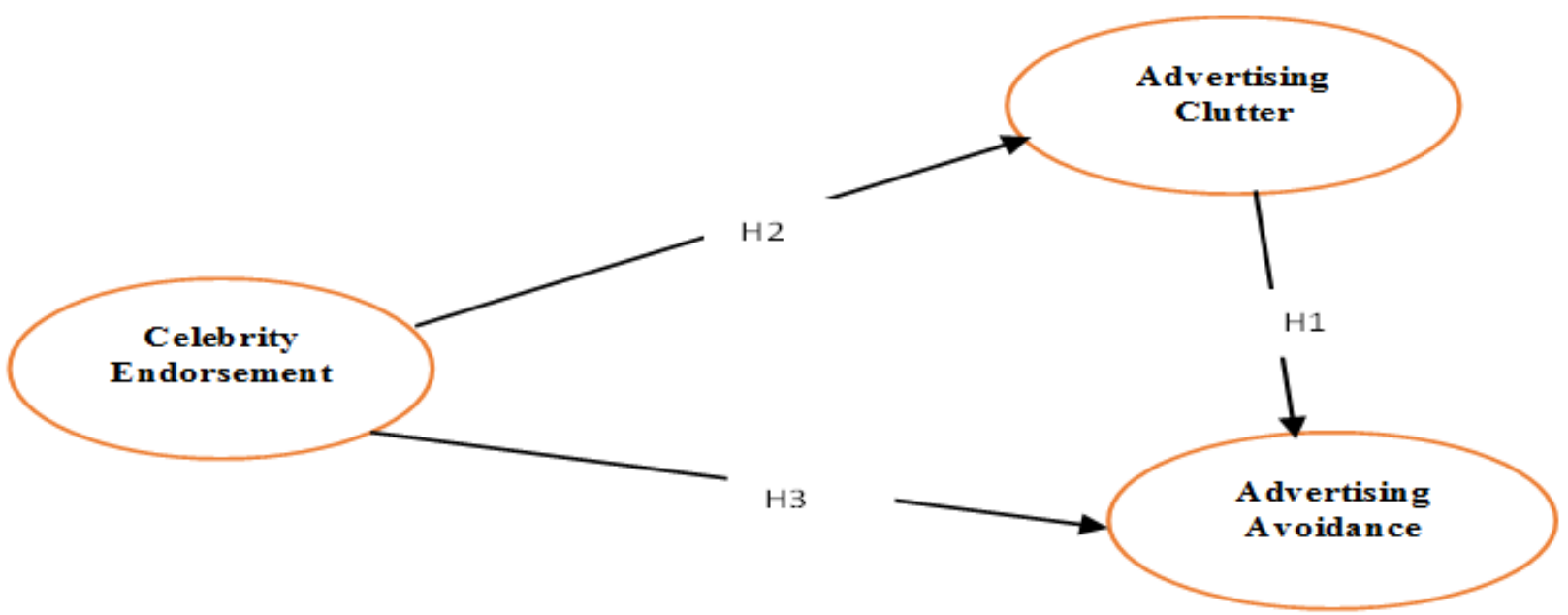

Figure 1. Conceptual model

\section{Materials and Methods}

Study design and sampling

The study tended to adopt a quantitative research method in testing the conceptual model about the influence relationship between the approved variables. The survey included a wide sample of Iraqi social network users, whose

Mosa, R. A. (2022). The Role of Celebrity Endorsements in Breaking Advertising Clutter and reducing Advertising Avoidance on Social Media Networks. International Research Journal of Management, IT and Social Sciences, 9(1), 203-220. https://doi.org/10.21744/irjmis.v9n1.2010 
number reached (837) respondents by using the random sampling method. Table 1 shows the Demographic data of the respondents surveyed in the study. It is noted from this table that the sample consisted of (523) males, whose percentage was $(62 \%)$ of the total sample, while the remaining percentage $(38 \%)$ was female. About age groups, the age group (17-25 years) achieved (37\%), which is the highest among the respondents. While (Bachelor) got the highest percentage in the educational background among the respondents (44\%).

Table 1

Demographic profile of the respondents

\begin{tabular}{lccc}
\hline & Variables & Frequency & Percent \\
\hline Gender & Male & 523 & $62 \%$ \\
Age & Female & 314 & $38 \%$ \\
& 17-25 Years & 311 & $37 \%$ \\
& 26-34 Years & 154 & $18 \%$ \\
Education Background & 35-43 Years & 290 & $35 \%$ \\
& 44 < Years & 82 & $10 \%$ \\
& High School & 118 & $14 \%$ \\
& Diploma Degree & 238 & $28 \%$ \\
& Bachelor's degree & 366 & $44 \%$ \\
& Master's Degree & 92 & $11 \%$ \\
& Doctorate Degree & 23 & $3 \%$ \\
\hline
\end{tabular}

$\mathrm{n}=837$, Sources: Authors' survey

\section{Data collection tool}

To reach the goals set by the study, a two-part questionnaire was used. The first section covered the personal information of the individuals surveyed, while the second section included questions related to the variables adopted in the conceptual model, with (17) questions, and this is explained in Appendix (1).

The study was guided by the previous literature in designing the questionnaire used to collect data, in addition to modifying some paragraphs so that the tool came out in line with what the current study seeks. The questions about celebrity endorsement were taken from (Gupta et al., 2017; CalvoPorral et al., 2021), while the questions about advertising clutter were taken from (Guardia, 2015), concerning the questions about the advertising avoidance variable were formulated from. The answers of the study sample were framed according to the Likert scale by five points. The questionnaire was distributed and answers about it were retrieved through the Internet.

\section{Data analysis methods}

To arrive at the results that explain the validity of the conceptual model of the study as well as the proposed hypotheses, the (SPSS) program and its associated applications were employed in analyzing the data obtained through the study tool "the questionnaire", and descriptive analysis techniques were used. Add to the use of Pearson's correlation, and regression analysis.

\section{Results and Discussions}

\subsection{Reliability and descriptive analysis}

Among the basic steps in the statistical analysis is to know the extent of consistency in the answers of the sample included in the survey. In this regard, the reliability test Alpha Cronbach was used. Table 2 presents the results of the reliability test for the main variables and sub-dimensions of the study. The results extracted in the mentioned table indicated values higher than the recommended standard (0.70) (Nunnally, 1978). The celebrity endorsement variable achieved the reliability coefficient $(0.853)$. While the advertising clutter variable achieved the value of the reliability coefficient (0.892), in contrast, the advertising avoidance variable recorded the reliability coefficient (0.831). It is clear 
from the reliability values achieved in Cronbach's alpha test that they reflect a high level of consistency of the measures and items used by the study.

On the other hand, Table 2. reveals the results of descriptive statistical analysis related to the nature of the answers of the study sample to the questions directed to them in the questionnaire. The same table showed that the celebrity endorsement variable recorded a mean (3.92) and a standard deviation (.804), the sub-dimensions of celebrity endorsement achieved means and levels of dispersion/standard deviation, respectively attractiveness $($ Mean= 3.73, Standard Deviation=.914), trustworthiness $($ Mean=3.97, Standard Deviation=.835), expertise $($ Mean=4.06, Standard Deviation=.768), which means that the respondents' responses were positive with the use of celebrities on social networks. Whilst the advertising clutter variable recorded a mean (3.97) and a standard deviation (.884), the subdimensions of advertising clutter recorded means and levels of standard deviation, respectively ads quantity (Mean=4.03, Standard Deviation=.761), competitive interference (Mean=3.89, Standard Deviation= .852), It is inferred that the respondents' answers tended to confirm the presence of high levels of advertising clutter on social networks. While the variable of advertising avoidance recorded a mean (4.16) and a standard deviation (.731), the subdimensions of advertising avoidance achieved mean and standard deviations, respectively cognitive (Mean=4.21, Standard Deviation=.726), behavior (Mean=4.11, Standard Deviation=.785), this means that most respondents confirmed that they are not interested in ads on social networks and tend to avoid them whenever possible.

Table 2

Results of reliability test \& descriptive statistics

\begin{tabular}{lcccc}
\hline Variables & $\begin{array}{c}\text { Number } \\
\text { of items }\end{array}$ & $\begin{array}{c}\text { Cornbrash's } \\
\text { Alpha }\end{array}$ & Mean & $\begin{array}{c}\text { Standard } \\
\text { Deviation }\end{array}$ \\
\hline $\begin{array}{l}\text { Independent Variable: } \\
\text { Celebrity Endorsement }\end{array}$ & & 0.853 & 3.92 & .804 \\
1.Attractiveness & 3 & 0.805 & 3.73 & .914 \\
2. Trustworthiness & 3 & 0.910 & 3.97 & .835 \\
3. Expertise & 3 & 0.872 & 4.06 & .768 \\
Dependent Variable.1 & & 0.892 & 3.97 & .884 \\
Advertising Clutter & 2 & 0.924 & 4.03 & .761 \\
1.Ads Quantity & 2 & 0.841 & 3.89 & .852 \\
2.Competitive Interference & & 0.831 & 4.16 & .731 \\
Dependent Variable .2 & & & & \\
Advertising Avoidance & 2 & 0.837 & 4.21 & .726 \\
1.Congitive & 2 & 0.806 & 4.11 & .785 \\
2.Behavior & & & & \\
\hline Source: Survey Data & & & & \\
\hline
\end{tabular}

Source: Survey Data

\subsection{Correlation analysis}

The results of Pearson's analysis of the relationship between the advertising clutter on social media networks and advertising avoidance indicate that there is a strong correlation, this is proven by the correlation coefficient $(\mathrm{r}=.695 * *$, $\mathrm{p}<0.01)$ shown in table 3. a strong correlation was observed between the advertisement's quantity and the variable of advertisement avoidance through the values of the correlation coefficient $\left(\mathrm{r}=.763^{* *}, \mathrm{p}<0.01\right)$. whilst, dimension of the competitive interference a moderate correlation was recorded in its relationship with the advertising avoidance variable, which was shown by the correlation coefficient $\left(\mathrm{r}=.589^{* *}, \mathrm{p}<0.01\right)$.

Table 3

Person's correlation analysis to correlation between ad clutter and ad avoidance

\begin{tabular}{lc}
\hline Variables & Values \\
\hline Advertising Clutter & $.695^{* *}$ \\
Ads Quantity & $763^{* *}$ \\
Competitive Interference & $.589^{* *}$ \\
\hline
\end{tabular}

Mosa, R. A. (2022). The Role of Celebrity Endorsements in Breaking Advertising Clutter and reducing Advertising Avoidance on Social Media Networks. International Research Journal of Management, IT and Social Sciences, 9(1), 203-220. https://doi.org/10.21744/irjmis.v9n1.2010 
The results of Pearson's analysis of the relationship between the celebrity endorsement and advertising clutter, as shown in Table 4 indicate a moderate correlation, this was confirmed by the correlation coefficient $(r=479 * *, p<$ 0.01). A very weak correlation was observed in the dimension of attractiveness in its relationship to the advertising clutter through the values of the correlation coefficient $\left(r=.181^{* *}, p<0.01\right)$. Whilst the dimension of trustworthiness recorded a strong correlation in its relationship with the advertising clutter variable, this was shown by the correlation coefficient $(\mathrm{r}=.692 * *, \mathrm{p}<0.01)$. While, the expertise dimension achieved a moderate correlation in its relationship with the variable of advertising clutter, and this is evident from the correlation coefficient $\left(.418^{* *}, \mathrm{p}<0.01\right)$.

Table 4

Person's correlation analysis to correlation between celebrity endorsement and breaking ad clutter

\begin{tabular}{lc}
\hline Variables & Values \\
\hline Celebrity Endorsement & $.479^{* *}$ \\
Attractiveness & $.181^{* *}$ \\
Trustworthiness & $.692^{* *}$ \\
\hline
\end{tabular}

The results of Pearson's analysis of the relationship between celebrity endorsement and advertising avoidance, as shown in Table 5. indicate a strong correlation, this was confirmed by the value of the correlation coefficient $\left(.706^{* *}\right.$, $\mathrm{p}<0.01)$. A weak correlation was observed in the dimension of attractiveness in its relationship to the advertising avoidance through the values of the correlation coefficient $(r=.201 * *, p<0.01)$. Whilst the dimension of trustworthiness recorded a strong correlation in its relationship with the advertising avoidance, this was shown by the correlation coefficient $\left(\mathrm{r}=.782^{*}, \mathrm{p}<0.01\right)$. Likewise, the expertise dimension achieved a strong correlation in its relationship with the advertising avoidance, this is evident from the correlation coefficient $(.631 * *, p<0.01)$.

Table 5

Person's correlation analysis to correlation between celebrity endorsement and reducing ad avoidance

\begin{tabular}{lc}
\hline Variables & Values \\
\hline Celebrity Endorsement & $.706^{* *}$ \\
Attractiveness & $.201^{* *}$ \\
Trustworthiness & $.782^{* *}$ \\
Expertise & $.631^{* *}$ \\
\hline
\end{tabular}

\subsection{Hypothesis test}

Table 6 presents the results of testing the impact relationship between the advertising clutter and the advertising avoidance, which revealed a strong influence relationship $\left(\beta=.764, \mathrm{R}^{2}=52\right.$, calculated $\left.\mathrm{T}=25.421\right)$, which means that advertising clutter has a significant role in advertising avoidance on social media networks. At the sub-dimension level, the results in the mentioned table showed a strong influence relationship between the quantitative clutter and the advertising avoidance $\left(\beta=.850, \mathrm{R}^{2}=57\right.$, calculated $\left.\mathrm{T}=32.521\right)$. Similarly, there was a strong effect relationship between the competitive interference and the advertising avoidance $\left(\beta=.633, \mathrm{R}^{2}=35\right.$, calculated $\left.\mathrm{T}=21.011\right)$.

Table 6

Results of regression analysis between ad clutter and ad avoidance

\begin{tabular}{lcccc}
\hline Independent Variables & $\beta$ & $\mathrm{R}^{2}$ & $\mathrm{~T}$ & \multicolumn{1}{c}{ Hypothesis } \\
\hline Advertising Clutter & .764 & .52 & 25.421 & H1- Accepted \\
Ads Quantity & .850 & .57 & 32.521 & H1-A. Accepted \\
Competitive Interference & .633 & .35 & 21.011 & H1-B. Accepted \\
\hline \multicolumn{2}{l}{ Note. $\mathrm{p}<0.01,($ T tabulated $=3.291)$} & & &
\end{tabular}

Table 7 illustrates the results of the influence relationship test between the celebrity endorsement and the advertising clutter, which confirmed that there is a moderate effect relationship $\left(\beta=.532, \mathrm{R}^{2}=.31\right.$, calculated $\left.\mathrm{T}=15.139\right)$, this means that celebrity endorsement plays a significant role in breaking the Advertising clutter on social networks. 
Moreover, the results in the mentioned table showed a weak influence relationship between the attractiveness and the advertising clutter $\left(\beta=.273, \mathrm{R}^{2}=.9\right.$, calculated $\left.\mathrm{T}=8.053\right)$. Conversely, a strong effect relationship was demonstrated between the trustworthiness and the advertising clutter $\left(\beta=.781, \mathrm{R}^{2}=.47\right.$, calculated $\left.\mathrm{T}=25.975\right)$. Whilst, there was a medium effect relationship between the expertise and the advertising clutter $\left(\beta .547, \mathrm{R}^{2}=.33\right.$, calculated $\left.\mathrm{T}=19.021\right)$.

Table 7

Results of regression analysis between celebrity endorsement and ad clutter

\begin{tabular}{lcccc}
\hline Independent Variables & $\beta$ & $\mathrm{R}^{\mathbf{2}}$ & $\mathrm{T}$ & Hypothesis \\
\hline Celebrity Endorsement & .532 & .31 & 15.139 & H2 - Accepted \\
Attractiveness & .273 & .9 & 8.053 & H2-A. Accepted \\
Trustworthiness & .781 & .47 & 25.975 & H2-B. Accepted \\
Expertise & .547 & .33 & 19.021 & H2-C. Accepted \\
\hline
\end{tabular}

Note. $\mathrm{p}<0.01,(\mathrm{~T}$ tabulated $=3.291)$

Table 8 shows the results of the effect relationship test between the celebrity endorsement and the advertising avoidance, which proved a very strong influence relationship $\left(\beta=.846, \mathrm{R}^{2}=.58\right.$, calculated $\left.\mathrm{T}=31.642\right)$, this means that celebrity endorsement has a vital role in reducing the advertising avoidance on social networks. In the same content, the results indicated in the mentioned table that there is a weak effect relationship between the attractiveness and the reduction in advertising avoidance $\left(\beta=.273, \mathrm{R}^{2}=.7\right.$, calculated $\left.\mathrm{T}=6.740\right)$. In contrast, a very strong effect relationship was confirmed between the trustworthiness and the reduction in advertising avoidance $\left(\beta=.872, \mathrm{R}^{2}=.45\right.$, calculated $\mathrm{T}=34.057)$. Whilst, a moderate effect relationship was demonstrated between the expertise and the reduction in advertising avoidance $\left(\beta .631, \mathrm{R}^{2}=.34\right.$, calculated $\left.\mathrm{T}=29.028\right)$.

Table 8

Results of regression analysis between celebrity endorsement and reducing ad avoidance

\begin{tabular}{lcccc}
\hline Independent Variables & $\beta$ & $\mathrm{R}^{2}$ & $\mathrm{~T}$ & Hypothesis \\
\hline Celebrity Endorsement & .846 & .58 & 31.642 & H3- Accepted \\
Attractiveness & .217 & .7 & 6.740 & H3-A. Accepted \\
Trustworthiness & .872 & .45 & 34.057 & H3-B. Accepted \\
Expertise & .631 & .34 & 29.028 & H3-C. Accepted \\
\hline
\end{tabular}

Note. $\mathrm{p}<0.01$, $(\mathrm{T}$ tabulated $=3.291)$

\section{Conclusion and Recommends}

The advertising clutter for a long time represented a variable that proved counterproductive on the effectiveness of promotional and advertising, and such clutter was not limited to traditional media, it extended to include the Internet and digital networks. Today, technological developments have brought the winds of change in the advertising landscape. This is evident through social networks that have contributed positively to removing time and space restrictions in front of marketers to address customers. However, many marketers did not employ these changes properly and went towards bombing customers with advertisements, where most believe Marketers that the attention of customers to the content of advertising messages will be achieved through the huge number of advertising and its frequent appearance. The efforts of marketers in advertising and promotion take a similar path to "throw dust in the eyes" and this will inevitably exacerbate the levels of perceived clutter on social networks. Therefore, the study sought to reveal the levels of advertising clutter on social networks and their relationship to the reactions of users of those networks about avoiding advertising, in addition to highlighting the ability of the celebrity endorsement strategy as a marketing tool to break the clutter and encourage users' in watching ads on those networks. According to the indicators provided by the results of the study, it is concluded that there are high levels of perceived advertising clutter among Iraqi social network users, which was the influential variable in generating advertisement avoidance behaviors. Thus, it is inferred that the effectiveness of advertisements on those networks in passing promotional messages to the customer's mind is weak. furthermore, the answers of the study sample supported the fact that a celebrity endorsement

Mosa, R. A. (2022). The Role of Celebrity Endorsements in Breaking Advertising Clutter and reducing Advertising Avoidance on Social Media Networks. International Research Journal of Management, IT and Social Sciences, 9(1), 203-220. https://doi.org/10.21744/irjmis.v9n1.2010 
strategy is an important tool in conveying persuasive messages that can penetrate the advertising clutter and reduce advertising avoidance behaviors among users of digital networks.

The study recommended that marketers should strive to formulate a promotional strategy in social networks based on building integrated advertising campaigns in their content of entertainment and information that customers see as valuable and useful. Especially, we live in an era that is most described as an information explosion and that customers have become more aware of receiving the marketing information. In other words, marketers should bear in mind that launching more advertising messages or being present on social networks such as Facebook, YouTube and Twitter are no longer enough to gain customer interest and achieve fame, but those Marketers should be keen on designing ads that can penetrate the advertising clutter and motivate customers to do more pay attention to the messages that appear in front of them when browsing digital networks. In general, marketers are supposed to be aware of the reasons or barriers behind the weak customer interest in viewing their ads on social media networks. In this aspect, Marketers should diligently use appropriate promotional and advertising tools to influence customers. Specifically, concerning the employ of celebrity endorsements by selecting the appropriate personals with physical and personality traits capable of attracting and persuading customers. In addition, the celebrity must have sufficient knowledge or expertise about a product that it will support to achieve the desired influence on the audience. Not to mention, the necessity of choosing the celebrity person who enjoys the public's trust in a way that draws a strong framework for the credibility of advertising from the customer's perspective. In reality, many customers have a negative perception of advertising as considering it to reflect the path marketers devote to achieving their goals through their claims about the product, which may be true in some situations, or enduring exaggeration, misinformation, or perhaps deception in others. More precisely, marketers need to take a careful path in choosing the celebrity who can convey marketing messages that instill sufficient confidence in the same customer.

\section{Conflict of interest statement}

The author declared that he have no competing interests.

Statement of authorship

The author has a responsibility for the conception and design of the study. The author has approved the final article.

Acknowledgments

I am grateful to two anonymous reviewers for their valuable comments on the earlier version of this paper. 


\section{References}

Adelabu, O. (2015). Social media, advertising messages and the youth: Any influence. Accessed on, 15(8), 2016.

Al Shuaili, A. H. A. (2016). Can advertising creativity overcome clutter?: affect, attention, and memory.

Anderson, S. P., \& De Palma, A. (2013). Shouting to be heard in advertising. Management Science, 59(7), 1545-1556.

Awasthi, A. K., \& Choraria, S. (2015). Effectiveness of celebrity endorsement advertisements: The role of customer imitation behaviour. Journal of Creative Communications, 10(2), 215-234.

Belanche, D., Flavián, C., \& Pérez-Rueda, A. (2017). User adaptation to interactive advertising formats: The effect of previous exposure, habit and time urgency on ad skipping behaviors. Telematics and Informatics, 34(7), 961-972. https://doi.org/10.1016/j.tele.2017.04.006

Brown, M., \& Point, K. (2011). How should you take TV advertising clutter into account?. Knowledge Point, May, 13.

Calvo-Porral, C., Rivaroli, S., \& Orosa-González, J. (2021). The Influence of Celebrity Endorsement on Food Consumption Behavior. Foods, 10(9), 2224.

Chen, J. (2021). 36 Essential social media marketing statistics to know for 2021. Sproutsocial. com.

Chinchanachokchai, S., \& de Gregorio, F. (2020). A consumer socialization approach to understanding advertising avoidance on social media. Journal of Business Research, 110, 474-483. https://doi.org/10.1016/j.jbusres.2020.01.062

Christian, O. S. (2020). Competitive advantage and organisational performance in selected firms. International Research Journal of Management, IT and Social Sciences, 7(5), 1-12. https://doi.org/10.21744/irjmis.v7n5.965

Cordero-Gutiérrez, R., \& Lahuerta-Otero, E. (2020). Social media advertising efficiency on higher education programs Eficiencia publicitaria de los medios sociales en programas de.

Cowden, A. G. (2014). Effect of social media marketing on traditional marketing campaigns in young Icelandic companies (Doctoral dissertation).

Cuomo, M. T., Foroudi, P., Tortora, D., Hussain, S., \& Melewar, T. C. (2019). Celebrity endorsement and the attitude towards luxury brands for sustainable consumption. Sustainability, 11(23), 6791.

Damour, M.J. (2019). Effect of Advertising on Sales Performance of Private organizations in Rwanda Case Study: Inyange Industries., Master Thesis, University of Rwanda.

Das, S., Dash, M., Sahoo, K., \& Mishra, U. S. (2018). Study on effectiveness of celebrity endorsements in print \& social media advertisements on the buying behaviour of consumers. Revista Espacios, 39(06).

de Luca, P., Ampò, A., Orciuolo, P., \& Venier, F. (2019). Who Is Shaping Search Engine Results in the Wine Industry? A Cross-Country Analysis. In MIC 2019: Managing Geostrategic Issues (pp. 149-150). University of Primorska Press.

Dhotre, M. P., \& Bhola, S. S. (2010). Analytical Study of Association Between Celebrity Advertising and Brand Recall. IUP Journal of Brand Management, 7.

Dong, K. (2019). Understanding how YouTube users experience personalized advertising and what leads to ad avoidance in the context of personalization., Master thesis, Jonkoping University.

Dzisah, W. E., \& Ocloo, C. E. (2013). Celebrity endorsement and consumer buying behaviour; enhancing the promotion function of marketing in the central business area of Accra, Ghana. European Journal of Business and Management, 5(25), 2013.

Erdoğmuş, İ., \& Ergun, S. (2016). Understanding university brand loyalty: the mediating role of attitudes towards the department and university. Procedia-Social and Behavioral Sciences, 229, 141-150. https://doi.org/10.1016/j.sbspro.2016.07.123

Falcão, J., \& Isaías, P. (2020). Perceptions and Attitude Toward Advertising on Social Networks and Search Engines: A Comparative Analysis. Journal of Internet Commerce, 19(4), 404-436.

ForgDog, (2013). The Advantages and Disadvantages of Celebrity Endorsements.

Fourberg, N., Serpil, T. A. Ş., Wiewiorra, L., Godlovitch, I., De Streel, A., Jacquemin, H., ... \& Lognoul, M. (2021). Online advertising: the impact of targeted advertising on advertisers, market access and consumer choice.

Freeman, K. S., \& Chen, C. C. (2015). Wither the impact of celebrity endorsement. Online Journal of Communication and Media Technologies, 5(December 2015-Special Issue), 213-237.

Freire, O., Quevedo-Silva, F., \& Scrivano, D. S. (2018). The effectiveness of celebrity endorsement in aspiring new celebrities: Examining the effects of brand, congruence, charisma and overexposure. RAUSP Management Journal, 53, 289-303.

Goh, W. K. (2018). Social media advertising: An exploration of marketing technique and tools to combat ad-blocking and ad-avoidance (Doctoral dissertation, Dublin, National College of Ireland).

Mosa, R. A. (2022). The Role of Celebrity Endorsements in Breaking Advertising Clutter and reducing Advertising Avoidance on Social Media Networks. International Research Journal of Management, IT and Social Sciences, 9(1), 203-220. https://doi.org/10.21744/irjmis.v9n1.2010 
Guardia, F. R. (2015). A Generalization Of Advertising Avoidance On Social Networks.

Gupta, R., Kishor, N., \& Verma, D. P. S. (2017). Construction and validation of a five-dimensional celebrity endorsement scale: introducing the pater model. British journal of marketing studies, 5(4), 15-35.

Gupta, S. (2009). How do consumers judge celebrities' irresponsible behavior? An attribution theory perspective. The Journal of Applied Business and Economics, 10(3), 1.

Ha, L., \& McCann, K. (2008). An integrated model of advertising clutter in offline and online media. International Journal of Advertising, 27(4), 569-592.

Hammer, P., Riebe, E., \& Kennedy, R. (2009). How clutter affects advertising effectiveness. Journal of Advertising Research, 49(2), 159-163.

Hani, S., Marwan, A., \& Andre, A. (2018). The effect of celebrity endorsement on consumer behavior: Case of the Lebanese jewelry industry. Arab Economic and Business Journal, 13(2), 190-196. https://doi.org/10.1016/j.aebj.2018.11.002

Ho, V. T. (2021). Advertising avoidance: a literature review. Independent Journal of Management \& Production, 12(1), 185-200.

Hocevar, K., Metzger, M. \& Flanaginet, A. (2017). Source Credibility, Expertise, and Trust in Health and Risk Messaging. Oxford Research Encyclopedia of Communication.

Hung, K. (2014). Why celebrity sells: A dual entertainment path model of brand endorsement. Journal of advertising, 43(2), 155-166.

Hussain, D. \& Khan, K. (2017). Understanding the Effectiveness of Celebrity Endorsements. International Marketing Journal, 9(1), 44-59.

Ifeanyichukwu, C. D. (2016). Effect of celebrity endorsements on consumers purchase decision in Nigeria. International Research Journal of Management, IT and Social Sciences, 3(9), 120-128.

Isosuo, H. (2016). Social media influencer marketing., Bachelor's Thesis, JAMK University of Applied Sciences.

Jagani, K. \& Goldsmith, R. (2018). Impact of Relevance and Clutter of Advertisement on Irritation - An Experimental Study on The Us and Indian Consumers.

Jain, S. (2012). Cluttered Market: Branding is the Key. International Journal of Management \& Business Studies, 2(3), 58-59.

Jolly, R. M., \& Mynavathi, L. (2013). Celebrity endorsement as an effective tool for destination marketing among occupation groups in Bangalore. Atna Journal of Tourism Studies, 8(2), 55-74.

Keller, K. L. (2009). Building strong brands in a modern marketing communications environment. Journal of marketing communications, 15(2-3), 139-155.

Kelly, L., Kerr, G., \& Drennan, J. (2010). Avoidance of advertising in social networking sites: The teenage perspective. Journal of interactive advertising, 10(2), 16-27.

Khan, A.M. (2017). Factors Influencing Consumers' Attitudes toward Social Media Marketing. MIS Review, 22(1/2), 21-40.

Kim, S. (2015). Effects of ad-video similarity, ad location, and user control option on ad avoidance and advertiserintended outcomes of online video ads (Doctoral dissertation, University of Minnesota).

Koshksaray, A. A., Franklin, D., \& Hanzaee, K. H. (2015). The relationship between e-lifestyle and Internet advertising avoidance. Australasian Marketing Journal (AMJ), 23(1), 38-48. https://doi.org/10.1016/j.ausmj.2015.01.002

Kowalewska, K. (2018). The effectiveness of celebrity endorsements in Polish magazines. Annales. Etyka w Życiu Gospodarczym, 21(4), 31-44.

Lee, S. Y., \& Cho, Y. S. (2010). Do web users care about banner ads anymore? The effects of frequency and clutter in web advertising. Journal of Promotion Management, 16(3), 288-302.

Li, W., \& Huang, Z. (2016). The research of influence factors of online behavioral advertising avoidance. American Journal of Industrial and Business Management, 6(09), 947.

Li, X., Zhang, Y., \& Yao, J. (2020). Avoidance Behavior toward Social Network Advertising: Dimensions and Measurement.

Li, Y., Chen, X., Tang, B. S., \& Wong, S. W. (2018). From project to policy: Adaptive reuse and urban industrial land restructuring in Guangzhou City, China. Cities, 82, 68-76. https://doi.org/10.1016/j.cities.2018.05.006

Lin, H. C. S., Lee, N. C. A., \& Lu, Y. C. (2021). The Mitigators of Ad Irritation and Avoidance of YouTube Skippable In-Stream Ads: An Empirical Study in Taiwan. Information, 12(9), 373.

Magnini, V. P., Honeycutt, E. D., \& Cross, A. M. (2008). Understanding the use of celebrity endorsers for hospitality firms. Journal of Vacation Marketing, 14(1), 57-69. 
Majid, J. (2020). The Power of Celebrity as a Medium of Coercing Behaviour - A Marks and Spencer's Case Study. Journal of Business and Social Science Review, 1(3), 29- 38.

Malik, A., \& Sudhakar, B. D. (2014). Brand positioning through celebrity Endorsement-A review contribution to brand literature. International Review of Management and Marketing, 4(4), 259.

Malik, K. \& Qureshi, M. (2016). The Impact of Celebrity Endorsement on Consumer Buying Behavior. Journal of Marketing and Consumer Research, 26, 112-127.

Manran, L. (2019). How influencers affect purchase intentions towards endorsed products: the role of influencers' match-up with the brand, payment and credibility (Doctoral dissertation).

Martin, K. D., \& Smith, N. C. (2008). Commercializing social interaction: The ethics of stealth marketing. Journal of Public Policy \& Marketing, 27(1), 45-56.

Mattke, J., Müller, L., \& Maier, C. (2018). Why do individuals avoid social media advertis-ing: A qualitative comparison analysis study.

Mishra, A. S. (2015). Brand-celebrity match and its impact on advertising effectiveness. DLSU Business \& Economics Review, 25(1), 16-27.

Muda, M., Musa, R., \& Putit, L. (2012). Breaking through the clutter in media environment: how do celebrities help?. Procedia-social and behavioral sciences, 42, 374-382. https://doi.org/10.1016/j.sbspro.2012.04.201

Mude, A., Ouma, R., \& Lentz, E. (2012). Responding to food insecurity: Employing the market information and food insecurity response analysis framework in rural Northern Kenya. The Journal of Development Studies, 48(12), 1731-1749.

Nan, X., \& Faber, R. J. (2004). Advertising theory: Reconceptualizing the building blocks. Marketing Theory, 4(1-2), 7-30.

Ndlela, T., \& Chuchu, T. (2016). Celebrity endorsement Advertising: Brand awareness, brand recall, brand loyalty as antecedence of South African young consumers' purchase behaviour. Journal of Economics and Behavioral Studies, 8(2 (J)), 79-90.

Negm, E., \& Tantawi, P. (2015). Investigating the impact of visual design on consumers' perceptions towards advertising. International Journal of Scientific and Research Publications, 5(4), 1-9.

Nelson, O., \& Deborah, A. (2017). Celebrity endorsement influence on brand credibility: A critical review of previous studies. Online Journal of Communication and Media Technologies, 7(1), 15-32.

Nelson-Field, K., Riebe, E., \& Sharp, B. (2013). More mutter about clutter: Extending empirical generalizations to Facebook. Journal of advertising research, 53(2), 186-191.

Neti, S., (2011). Social media and its role in marketing. International Journal of Enterprise Computing and Business Systems, 1(2), 1-15.

Nguyen, N. T. (2021). The Influence of Celebrity Endorsement on Young Vietnamese Consumers' Purchasing Intention. The Journal of Asian Finance, Economics, and Business, 8(1), 951-960.

Nilsson, C. P. (2006). Attention to advertising (Doctoral dissertation).

Niu, X., Wang, X., \& Liu, Z. (2021). When I feel invaded, I will avoid it: The effect of advertising invasiveness on consumers' avoidance of social media advertising. Journal of Retailing and Consumer Services, 58, 102320. https://doi.org/10.1016/j.jretconser.2020.102320

Nunnally, J. C. (1978). Psychometric Theory: $2 d$ Ed. McGraw-Hill.

Olmedo, A., Milner-Gulland, E. J., Challender, D. W., Cugnière, L., Dao, H. T. T., Nguyen, L. B., ... \& Veríssimo, D. (2020). A scoping review of celebrity endorsement in environmental campaigns and evidence for its effectiveness. Conservation Science and Practice, 2(10), e261.

Onișor, L. F., \& Ioniță, D. (2021). How advertising avoidance affects visual attention and memory of advertisements. Journal of Business Economics and Management, 22(3), 656-674.

Ordenes, F., Grewal, D., Ludwig, S., Ruyter, K., Mahr, D. \& Wetzels, M. (2018). Cutting through Content Clutter: How Speech and Image Acts Drive Consumer Sharing of Social Media Brand Messages, Journal of Consumer Research, Oxford University Press, 45(5), 1-25.

Ouyang, S. (2015). An examination of ad clutter and task orientation on avoidance of social media advertising: a psychological reactance perspective. University of Missouri-Columbia.

Poturak, M., \& Kadrić, N. (2013). Students Perceptions about Celebrity Endorsement. European Researcher, (9-2), 2331-2340.

Rafique, M., \& Zafar, Q. U. A. (2012). Impact of celebrity advertisement on customers' brand perception and purchase intention. Asian Journal of Business and Management Sciences, 1(11), 53-67.

Mosa, R. A. (2022). The Role of Celebrity Endorsements in Breaking Advertising Clutter and reducing Advertising Avoidance on Social Media Networks. International Research Journal of Management, IT and Social Sciences, 9(1), 203-220. https://doi.org/10.21744/irjmis.v9n1.2010 
Raluca, C. A. (2012). Celebrity endorsement strategy. Annals of the „Constantin Brâncuşi” University of Târgu Jiu, Economy Series,(3), 75-79.

Rejón-Guardia, F., \& Martínez-López, F. J. (2014). Online advertising intrusiveness and consumers' avoidance behaviors. In Handbook of strategic e-business management (pp. 565-586). Springer, Berlin, Heidelberg.

Richards, T. (2020). Investigating the determinants behind advertisement-avoidance on social networking sites by Generation Z students in Durban, South Africa (Doctoral dissertation, The IIE).

Rogala, A. (2015). Towards A New Paradigm Of Integrated Marketing Communication?. In DIEM: Dubrovnik International Economic Meeting (Vol. 2, No. 1, pp. 698-709). Sveučilište u Dubrovniku.

Rojas-Méndez, J. I., Davies, G., \& Madran, C. (2009). Universal differences in advertising avoidance behavior: A cross-cultural study. Journal of Business Research, 62(10), 947-954. https://doi.org/10.1016/j.jbusres.2008.08.008

Rosengren, S. (2008). Facing clutter on message competition in marketing communications. Economic Research Institute, Stockholm School of Economics (EFI),.

Rosengren, S., \& Dahlén, M. (2006). Brand-slogan matching in a cluttered environment. Journal of Marketing Communications, 12(4), 263-279.

Rosenholtz, R., Li, Y., Mansfield, J., \& Jin, Z. (2005). Feature congestion: a measure of display clutter. In Proceedings of the SIGCHI conference on Human factors in computing systems (pp. 761-770).

Rotfeld, H. J. (2006). Understanding advertising clutter and the real solution to declining audience attention to mass media commercial messages. Journal of Consumer Marketing.

Rotfeld, H. J., \& Stafford, M. R. (2006). Pragmatism and Realities for Understanding the Advertising and Public Policy Literature. In American Academy of Advertising. Conference. Proceedings (Online) (p. 209). American Academy of Advertising.

Saleem, F. (2017). The impact of celebrity endorsement on brand affection and purchase intention: The mediating role of word of mouth.

Schlecht, C. (2003). Celebrities' impact on branding. Center on Global Brand Leadership, Columbia: Columbia Business School.

Schouten, A. P., Janssen, L., \& Verspaget, M. (2020). Celebrity vs. Influencer endorsements in advertising: the role of identification, credibility, and Product-Endorser fit. International journal of advertising, 39(2), 258-281.

Seyedghorban, Z., Tahernejad, H., \& Matanda, M. J. (2016). Reinquiry into advertising avoidance on the internet: A conceptual replication and extension. Journal of Advertising, 45(1), 120-129.

Sharma, K. I. R. A. N., \& Kumar, S. S. (2013). Celebrity endorsement in advertising; can it lead to brand loyalty in the long run. International Journal of Marketing, Financial Services, and Management Research, 2(3), 73-79.

Speck, P. S., \& Elliott, M. T. (1997). Predictors of advertising avoidance in print and broadcast media. Journal of Advertising, 26(3), 61-76.

Subbiah, P. V., \& Sathish, A. S. (2020). Exploring The Influences Of Celebrity Endorsement On Purchase Intention And Brand Loyalty Among Rural Youth. Journal of Critical Reviews, 7(6), 426-431.

Subramanian, K. R. (2015). Advertising clutter and consumer apathy. GE-International Journal of Management Research, 3(6), 309-22.

Tanjung, S., \& Hudrasyah, H. (2019). The impact of celebrity and non-celebrity endorser credibility in the advertisement on attitude towards advertisement, attitude towards brand, and purchase intention. Jurnal Ekonomi dan Bisnis.

Teixeira, T. S., \& Stipp, H. (2013). Optimizing the Amount of Entertainment in Advertising: What's So Funny about Tracking Reactions to Humor?. Journal of Advertising Research, 53(3), 286-296.

Tran, T. P. (2017). Personalized ads on Facebook: An effective marketing tool for online marketers. Journal of Retailing and Consumer Services, 39, 230-242. https://doi.org/10.1016/j.jretconser.2017.06.010

Truong, Y., \& Simmons, G. (2010). Perceived intrusiveness in digital advertising: strategic marketing implications. Journal of strategic marketing, 18(3), 239-256.

Vratonjic, N., Manshaei, M. H., Grossklags, J., \& Hubaux, J. P. (2013). Ad-blocking games: Monetizing online content under the threat of ad avoidance. In The economics of information security and privacy (pp. 49-73). Springer, Berlin, Heidelberg.

Vukasovic, T. (2013). Building successful brand by using social networking media. Journal of Media and Communication Studies, 5(6), 56.

Wang, S. \& Scheinbaum, A. (2017). Trustworthiness Trumps Attractiveness and Expertise. Journal of Advertising Research, December, pp.1-39. 
Wijenayake, S., \& Pathirana, I. (2019). A study on factors influencing online behavioral advertising avoidance (Oba): Special reference to Sri Lankan online advertising. Management Science Letters, 9(8), 1281-1288.

Mosa, R. A. (2022). The Role of Celebrity Endorsements in Breaking Advertising Clutter and reducing Advertising Avoidance on Social Media Networks. International Research Journal of Management, IT and Social Sciences, 9(1), 203-220. https://doi.org/10.21744/irjmis.v9n1.2010 
Appendix-1

(Questionnaire Items)

\begin{tabular}{|c|c|c|c|c|c|}
\hline \multicolumn{2}{|r|}{ Questions } & \multirow{2}{*}{$\begin{array}{l}\text { Strongly } \\
\text { Totally } \\
\qquad 1 \quad 2 \\
\text { Disagree } \\
\text { agree }\end{array}$} & & & \\
\hline & & & & & \\
\hline & Celebrity Endorsement & & & & \\
\hline & Attractiveness & & & & \\
\hline 1. & $\begin{array}{l}\text { I pay good attention to ads featuring beautiful celebrities on } \\
\text { social media networks. }\end{array}$ & & & & \\
\hline 2. & $\begin{array}{l}\text { Celebrities on social networks who endorse the products are } \\
\text { handsome and classy. }\end{array}$ & & & & \\
\hline \multirow[t]{2}{*}{3.} & $\begin{array}{l}\text { Celebrities in social media networks are good references for } \\
\text { buying products. }\end{array}$ & & & & \\
\hline & Trustworthiness & & & & \\
\hline 4. & $\begin{array}{l}\text { Celebrities who endorsed products and brands on social media } \\
\text { networks seem to be honest. }\end{array}$ & & & & \\
\hline 5. & $\begin{array}{l}\text { Celebrities recommending brands on social media networks } \\
\text { seem to be trusted. }\end{array}$ & & & & \\
\hline \multirow[t]{2}{*}{6.} & $\begin{array}{l}\text { I think that celebrities on social media networks have a } \\
\text { convincing credibility }\end{array}$ & & & & \\
\hline & Expertise & & & & \\
\hline 7. & $\begin{array}{l}\text { Celebrities on social networks are knowledgeable who } \\
\text { recommend products }\end{array}$ & & & & \\
\hline 8. & $\begin{array}{l}\text { Celebrities on social networks who recommend products are } \\
\text { well qualified }\end{array}$ & & & & \\
\hline \multirow[t]{3}{*}{9.} & $\begin{array}{l}\text { Celebrities on social networks are well-informed about the } \\
\text { products they recommend in advertisements. }\end{array}$ & & & & \\
\hline & Advertising Clutter & & & & \\
\hline & Ads Quantity & & & & \\
\hline 10. & $\begin{array}{l}\text { I think the number of ads on social media networks is } \\
\text { excessive. }\end{array}$ & & & & \\
\hline \multirow[t]{2}{*}{11.} & $\begin{array}{l}\text { I think the quantity of ads on social media networks is } \\
\text { annoying. }\end{array}$ & & & & \\
\hline & Competitive Interference & & & & \\
\hline 12. & $\begin{array}{l}\text { I think the wide spectrum of brands advertised on social media } \\
\text { networks is Interfering and Obtrusive. }\end{array}$ & & & & \\
\hline \multirow[t]{3}{*}{13.} & $\begin{array}{l}\text { I feel that social media ads are distracting due to the many } \\
\text { brands advertised. }\end{array}$ & & & & \\
\hline & Advertising Avoidance & & & & \\
\hline & Cognitive & & & & \\
\hline 14. & I don't pay any attention to social media networks ads. & & & & \\
\hline \multirow[t]{2}{*}{15.} & I ignore ads on social media networks. & & & & \\
\hline & Behavior & & & & \\
\hline 16. & I press the skip button when seeing ads on social networks & & & & \\
\hline 17. & I use blocking software towards social media networks ads & & & & \\
\hline
\end{tabular}

